\title{
EOSINOPHIL LEVELS IN THE ACUTE PHASE OF EXPERIMENTAL CHAGAS' DISEASE
}

\section{SUMMARY}

Eosinophil dynamics, in bone marrow, blood and peritoneal exudate, of resistant C57B1/6 (C57) and susceptible A/Snell (A/Sn) mice was comparatively studied during the acute phase of infection by Trypanosoma cruzi $Y$ strain.

A decline was observed in bone marrow eosinophil levels in $\mathrm{A} / \mathrm{Sn}$, but not in C57 mice, soon after infection, those of the former remaining significantly below those of the latter up to the $4^{\text {th }}$ day of infection. Bone marrow eosinophil levels of C57 mice declined subsequently to levels comparable to those of A/Sn mice, the number of these cells in this compartment remaining $50 \%$ those of non infected controls, in both strains, up to the end of the experiment on the $14^{\text {th }}$ day of infection.

The fluctuations in eosinophil levels in blood and peritoneal space were similar in both mice strains studied. Concomitantly with depletion of eosinophils in the marrow, depletion in blood and a marked rise of these cells in the peritoneal space, initial site of infection, occurred in both strains.

The difference in eosinophil bone marrow levels, between C57 and A/Sn mice, observed in the first four days of infection, suggests a higher eosinopoiesis capacity of the former in this period, which might contribute to their higher resistance to T. cruzi infection.

KEY WORDS: Experimental Chagas' disease; Mice strains; Eosinophil kinetics.

\section{INTRODUCTION}

The participation of eosinophils in host defense mechanisms to helminth infection and the "in vitro" killing of various parasites by eosino phils from different species has been demons trated, as reviewed by GLEICH \& ADOLPH SON (1986). "In vitro" antibody-dependent ki lling of T. cruzi blood-stream forms, by a variety of cell types, among which rat, mouse and hu man eosinophils has been documented ${ }^{9.12 .16}$. The intracellular destruction of $\mathbf{T}$. cruzi amastigotes by eosinophils, "in vitro", has also been reported and the evidences point to a role for the granule proteins in the lytic process of both, the trypo mastigote and the amastigote forms of the parasite ${ }^{10,11.13 .19}$. The participation of eosinophils in defence mechanisms against T. cruzi "in vivo" has not been determined.

For a better understanding of the "in vivo" mechanisms of T. cruzi destruction, some authors have taken advantage of the wide spec trum of resistance to this parasite of the various

Rescarch supported by CNPq - Proc. 40337884

(1) Instituto de Medicina Tropical de Sảo Paulo. Laboratorio de Alergia e Imunopatologia (LIM .51 HCFMUSPI. Av Dr. Enéas de Carvalho Aguiar, 470. CEP 05403 Sáo Paulo. SP. Brasil.

(2) Fellow of "Fundaçāo para o Desenvolvimento e Aprimoramento de Profissionais" (FUNDAP), Sâo Paulo, Brasil 
NAKHLE. M. C.: MENEZES, M. da C. S. de \& IRULEGUI, I. - Eosinophil levels in the acute phase of experimental Chagas' disease. Rev. Inst. Med. trop. S. Paulo, 31(6): 384 391, 1989.

isogenic mice strains ${ }^{4,17,18}$ and tried to correlate it to different parameters, including the inten sity and type of cells of the inflammatory process $^{4}$, as well as the bone marrow eosinophil levels ${ }^{14}$ during infection. ANDRADE et al. $^{4}$ reported that, during the acute phase of infection with the $21 \mathrm{SF} \mathbf{T}$. cruzi strain, the susceptible mice strains responded with a mild inflammatory process with predominance of mononuclear cells, while the resistant ones presented an intense inflammatory reaction with mononuclear and polymorphonuclear cells. ROWLAND \& SIBLEY-PHILLIPS ${ }^{14}$ observed an increase in eosinophil bone marrow percent during infection with the Brazil strain of $\mathbf{T}$. cruzi, in both $\mathrm{C}_{3} \mathrm{H}$ (He) and C57B 1/6 mice, susceptible and resistant to this strain respectively, with a peak coincident with that of parasitemia, on the $28^{\text {th }}$ day of infection.

To further investigate the role of eosinophils in the resistance to $\mathbf{T}$. cruzi "in vivo", we have now studied the dynamics of eosinophils during the acute phase of infection, of two isogenic strains of mice with different susceptibility to T. cruzi, with the $Y$ strain of the parasite, a type I strain according to ANDRADE classification ${ }^{2}$, which, contrary to the Brazil one, presents high replication and, consequently, high virulence, as well as an early parasitemic peak around the 8- $9^{\text {th }}$ day of infection in the resistant strains of mice.

\section{MATERIAL A.ND METHODS}

Parasites - Bloodstream forms of T. cruzi $Y$ strain were maintained by serial passages in Swiss albino mice. Infected blood was collected by heart puncture, using heparin ( 5 units $/ \mathrm{ml}$ ) as anticoagulant

Animals - Ten to 12 weeks old, female C57B1/6 (C57) and A/Snell (A/Sn) mice, bred in the animal house of the University of Sano Paulo Medical School, were used.

Infection - The animals were infected by i.p. inoculation of $5 \times 10^{2}$ trypomastigotes of $\mathbf{T}$. cruzi for observation of each mouse strain resis tance to the parasite and with $10^{4}$ for the study of eosinophil kinetics. The parasites were isolated from blood by the method of ALCANTARA \& BRENER ${ }^{1}$, for inoculation.
Cells collection - Blood was collected from the axillary plexus of anesthetyzed mice, which were subsequently bled to death, to avoid contamination of peritoneal cells with blood leucocytes. Peritoneal cells were obtained by lavage and aspiration with Hanks Balanced Salt Solution containing 5 units of heparin per $\mathrm{ml}$ (HBSS/ heparin). Bone marrow cells were collected from both femurs in HBSS/heparin and the clumps were dissociated by aspiration through siliconized glass pipets. The cells were washed and re suspended in the same medium.

Cells count - Aliquots of bone marrow, blood and peritoneal exudate cells suspensions were appropriately diluted in a methylene blue solution in $2 \%$ acetic acid for nucleated cells count in bone marrow and total leukocytes count in the two other compartments. Eosino phils from the same compartments were coun ted in an hemacytometer after staining with DIS COMBE's stain?. These counts were done, 1, 2, 4, $6,8,11$ and 14 days after infection with $\mathbf{T}$. cruzi $\mathrm{Y}$ strain, in 10 mice of each strain for each interval of time after infection, as well as for controls. The percentage of eosinophils in the different compartments was estimated from the absolute counts of eosinophils and that of either nucleated cells in bone marrow or total leukocytes in blood and peritoneal exudates.

Parasitemia - The number of parasites per milliliter of blood was determined by hemacy to meter counting of live parasites, after $10 \mathrm{x}$ dilution of blood in $0.87 \%$ ammonium chloride.

Course of Infection - Parasitemia and mortality were observed in 10 mice of each strain, inoculated with $5 \times 10^{2}$ bloodstream forms of $\mathbf{T}$. cruzi.

Statistical analysis - Due to the great variability observed in each group for parasitemia and eosinophil counts, the median and quartiles, instead of mean and standard deviation, were determined, to evaluate the central tendency and dispersion, respectively, for these values.

The Mann-Whitney test ${ }^{6}$ was used for com paring parasitemia and cell counts, either be tween the two mice strains studied or between infected mice of each strain and its respective control. 
NAKHLE, M. C.; MENEZES, M. da C. S. de \& IRULEGUI, I. - Eosinophil levels in the acute phase of experimental Chagas' disease. Rev. Inst. Med. trop. S. Paulo, 31(6): 384-391, 1989

The harmonic mean of survival time, in days, was calculated $^{5}$ for each strain.

\section{RESULTS}

Mean survival time and parasitemia - Our results for the harmonic mean of survival time in days, calculated from the observed mortality, for mice inoculated i.p. with $5 \times 10^{2}$ trypomastigotes of $\mathbf{T}$. cruzi Y strain, were 120.0 for those of the C57 and 18.0 for those of the A/Sn strain, in one of three experiments in which the results were similar. In the same experiment, parasi temia was significantly lower in the C57 as compared to that of $\mathrm{A} / \mathrm{Sn}$ mice, during the whole period of patency (Fig. 1). While parasitemia in the former fell after the $10^{\text {th }}$ day, that of the A/Sn strain remained high up to the $14^{\text {th }}$ day of infection, when death of these mice started to occur.

Eosinophil levels - The yield of femoral marrow eosinophils from the C57 mice increased slightly during the first 24 hours after infection, maintaining a plateau up to the $4^{\text {th }}$ day, to decrease thereafter, while in the $\mathrm{A} / \mathrm{Sn}$ mice eosinophil loss from the marrow began promptly following trypanosomes inoculation. Both mice strains presented a marked depletion of these cells in femoral marrow, from the $8^{\text {th }}$ day on, to levels approximately 8 -fold lower those of non infected controls to termination of the experi ment (Fig. 2). Relative bone marrow eosinophil levels ( Fig. 3) of C57 mice did not increase during the first two days, but presented a marked peak on the $4^{\text {th }}$ day of infection. Absolute as well as relative bone marrow eosinophil levels were sig nificantly higher in the C57 as compared to $\mathrm{A} / \mathrm{Sn}$ mice, on days 1 to 4 of infection. The lowest abso lute eosinophil levels in bone marrow, in both strains of mice occurred concomitantly with patency of parasitemia (Fig. 1 and 2). The difference

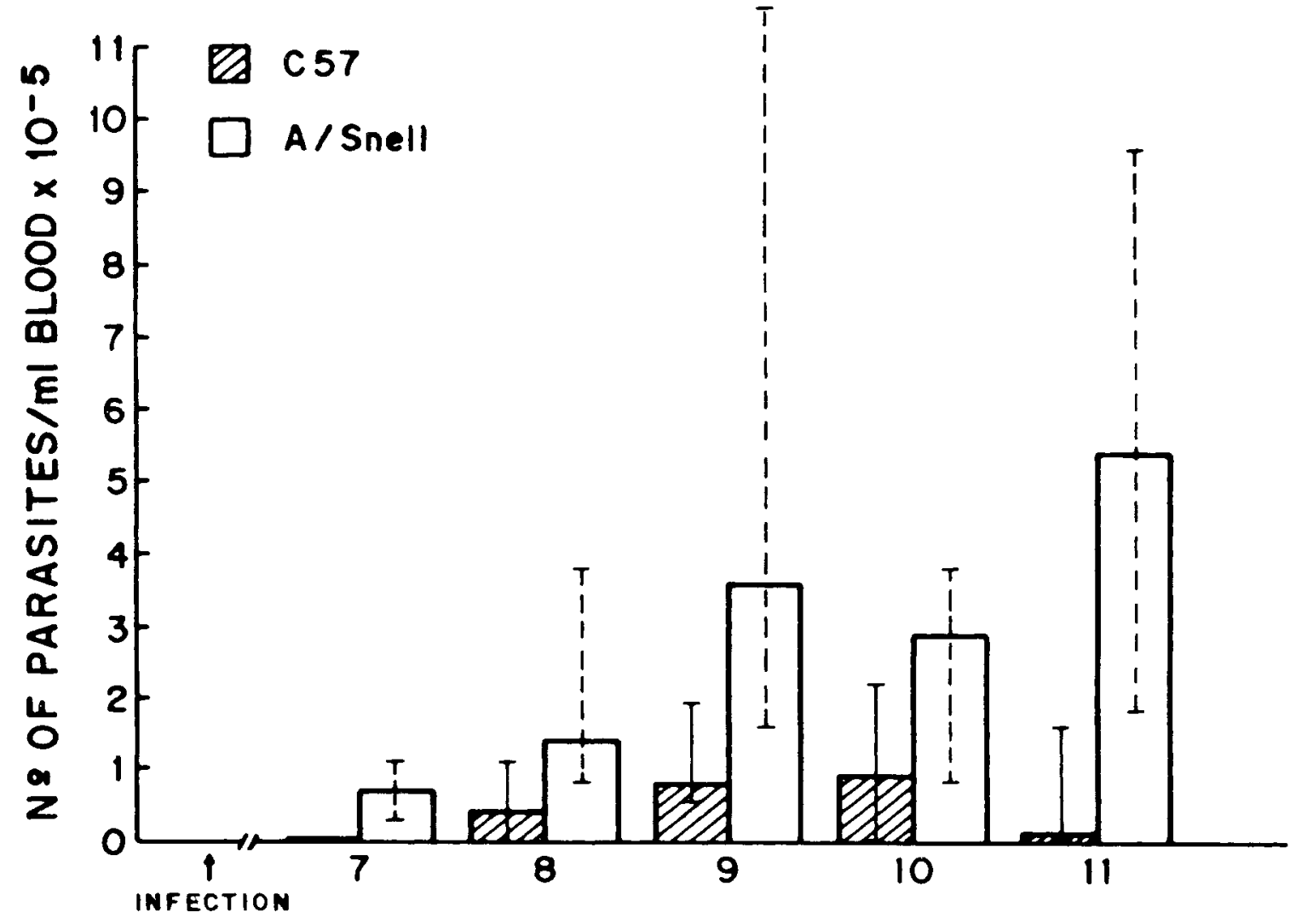

DAYS AFTER INFECTION

Fig. 1 - The course of parasitemia (median and quartiles) in C57B 6 and in A Snell mice infected with $5 \times 10^{2}$ trypomastigotes of $\mathbf{T}$. cruzi Y strain 
NAKHLE, M. C.; MENEZES, M. da C. S. de \& IRULEGUI. 1. - Eosinophil levels in the acute phase of experimental Chagas' disease. Rev. Inst. Med. trop. S. Paulo, 31(6): 384-391, 1989

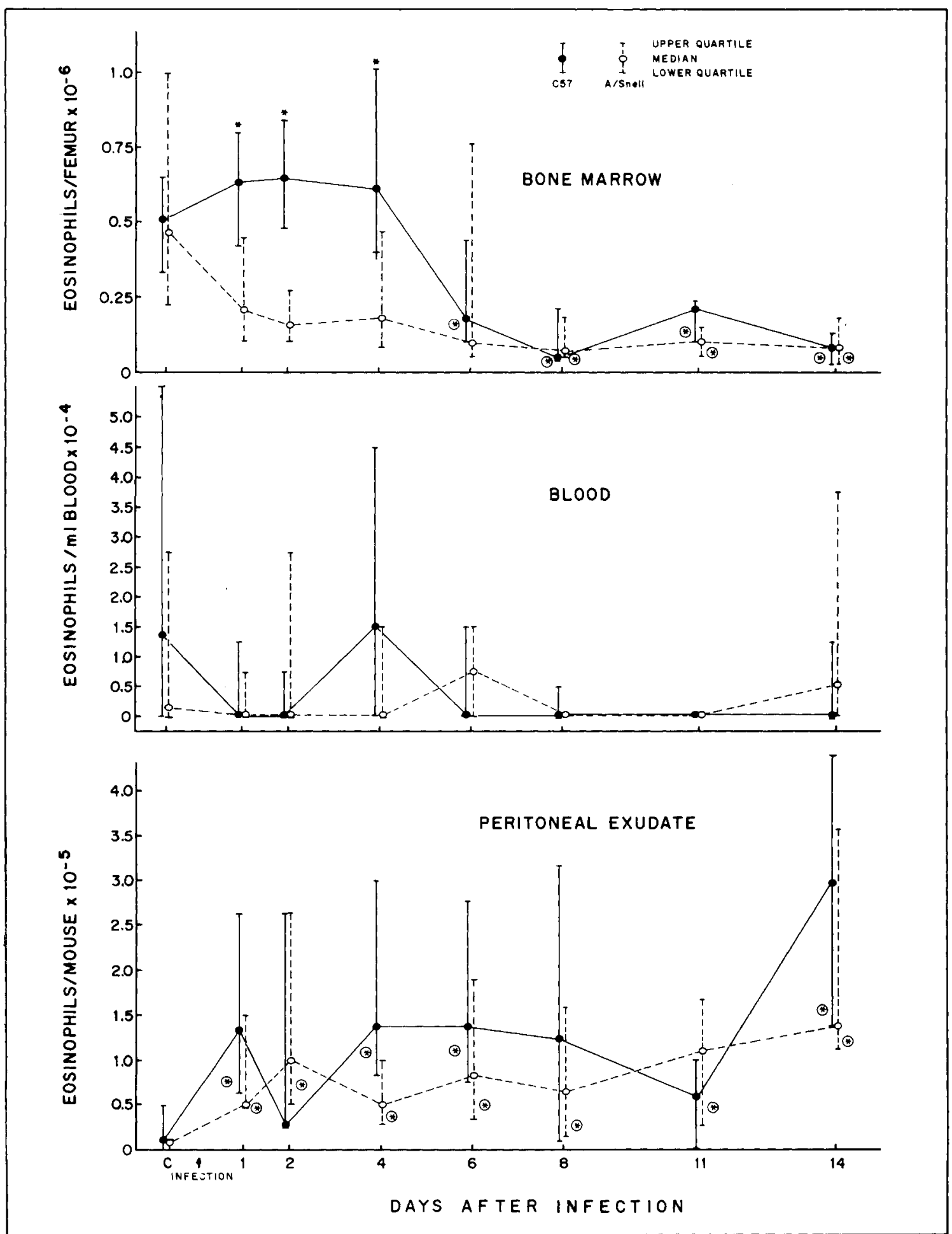

Fig. 2 - Absolute eosinophil levels in bone marrow, blood and peritoneal space of C57B1/6 (solid lines) and A:Snell (dashed lines mice, infected with $T$, cruzi $Y$ strain. Each point represents the median of eosinophil levels of at least 10 mice. significant difference between the two strains of mice at the 0.05 level. $\odot=$ significant difference from non infected controls at the 0.05 level. 
NAKHLE, M. C.: MENEZES, M. da C. S. de \& IRULEGUI. I. - Eosinophil levels in the acute phase of experimental Chagas disease. Rev. Inst. Med. trop. S. Paulo, 31(6): 384 391, 1989

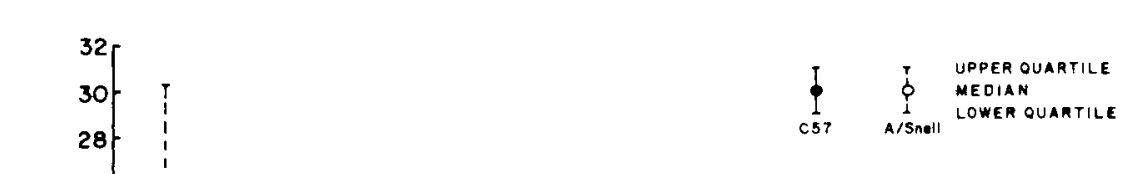

BONE MARROW
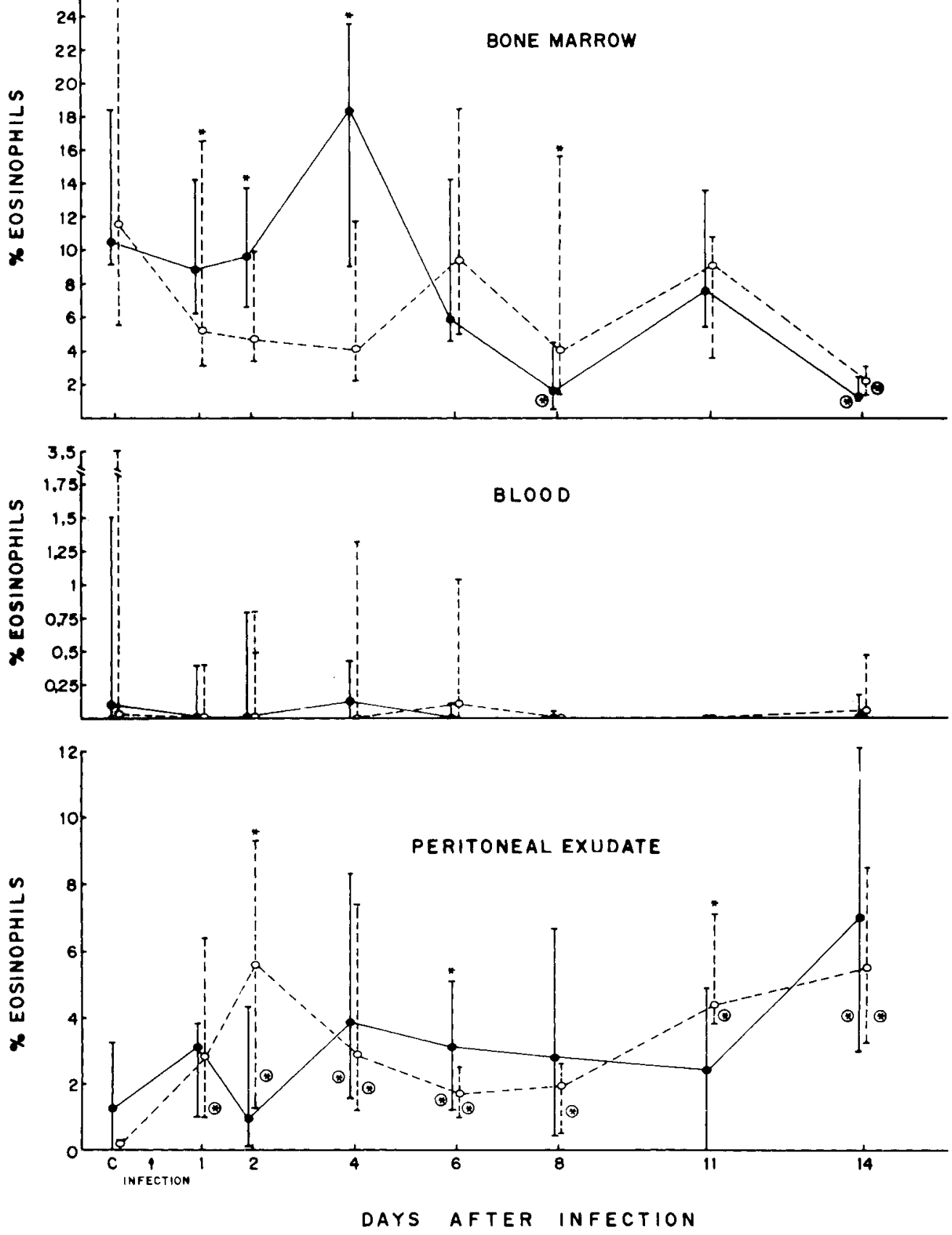

Fig. 3 -- Eosinophil percent in bone marrow, blood and peritoneal spacc of C57B1 6 (solid lines) and A Snell /dashed lines) mice infected with $\mathbf{T}$. cruzi $Y$ strain. Each point represents the median of eosinophil percents of at least $10 \mathrm{mice}$. $=$ difference between the two strains of mice at the 0.05 level of significance. $\bigcirc=$ significant difference trom non infected controls at the 0.05 leve.1. 
NAKHLE, M. C.: MENEZES, M. da C. S. de \& IRULEGUI, I. - Eosinophil levels in the acute phase of experimental Chagas' disease. Rev. Inst. Med. trop. S. Paulo, 31(6): 384 391, 1989.

in bone marrow eosinophil relative levels, be tween control and infected mice, in this period of time (days 6 to 14 ) was less accentuated than the difference in absolute levels, which declined to approximately 10 -fold in the $\mathrm{C} 57$ and 6 -fold in $\mathrm{A} / \mathrm{Sn}$ mice the respective control levels.

The median of blood eosinophil counts of A/Sn controls $\left(0.13 \times 10^{4} / \mathrm{ml}\right.$ blood) was lower than that of C57 controls $\left(1.4 \times 10^{4} / \mathrm{ml}\right.$ blood). Eosino phil blood levels declined soon after infection and remained below $10^{3}$ cells $/ \mathrm{ml}$, in mice from both strains, excepting the $4^{\text {th }}$ day for the $\mathrm{C} 57$ and the $6^{\text {th }}$ and $14^{\text {th }}$ days of infection for the A/Sn strain (Fig. 2 and 3). No significant differences were observed in blood absolute and relative eo sinophil counts, either between the two mice strains or between infected mice and its respective controls, though.

Peritoneal eosinophil absolute (Fig. 2) and relative (Fig. 3 ) levels were significantly higher in infected mice of both strains as compared to the respective controls, during most of the period of infection studied, the $\mathrm{C} 57$ mice presenting a marked rise after the $11^{\text {th }}$ day of infection, to levels approximately 11 -fold those of non infec ted controls on the $14^{\text {tin }}$ day, when the experi ment was terminated. No significant differences in peritoneal eosinophil absolute levels were observed between both strains of mice. Eosinophil levels in bone marrow and peritoneal space were observed to be equivalent for non infected controls of both strains of mice.

Fluctuations in eosinophil absolute levels, in blood and peritoneal space, paralleled the re lative ones, which indicates that the former were not a consequence of fluctuations in total leukocyte levels, but in eosinophil percent in these compartments.

\section{DISCUSSION}

TRISCHMANN et al. ${ }^{18}$ observed resistance of the $\mathrm{C} 57$ and susceptibility of the $\mathrm{A} / \mathrm{J}$ inbred mice to the Brazil strain of $\mathbf{T}$. cruzi, a strain described in the literature as being of slow replica tion, low virulence and late parasitemia peak, behaving, thus, in a similar way as those classified as type III strains by ANDRADE ${ }^{2}$. The same pattern of resistance was observed by us, in the present study, of a C57 and an A strain of mice, to the $\mathbf{T}$. cruzi $Y$ strain, a type I strain ${ }^{2}$, of fast replication and high virulence. ANDRADE et al. ${ }^{4}$ observed a high susceptibility of six mice strains, including a C57 one, to the Peruvian T. cruzi strain, another type I strain, with a mean survival time varying from 11.1 to 14.3 days. This discrepancy between their and our results may be due to the great difference in the inoculum used to infect the animals, that used by ANDRA$\mathrm{DE}$ et al. ${ }^{4}$ being 200 -fold the one we have used.

ROWLAND \& SIBLEY-PHILLIPS ${ }^{14}$ obser ved a positive correlation between parasitemia and bone marrow eosinophil content during in fection of mice with the Brazil strain of $\mathbf{T}$. cruzi, while we observed very low absolute and relative eosinophil levels in this compartment during patency of parasitemia. The difference in the characteristics of the $\mathbf{T}$. cruzi strains used in both studies may be responsible for these conflicting results, since the intensity of the eosinophilic response is dependent, in part, upon the specific immune response to the parasite and, apparently, different $\mathbf{T}$. cruzi strains determine a diverse degree of immune response in mice ${ }^{3}$.

The fluctuations in eosinophil numbers we observed in the different compartments studied, during the acute phase of infection with T. cruzi $\mathrm{Y}$ strain, was similar for $\mathrm{C} 57$ and $\mathrm{A} / \mathrm{Sn}$ mice, the eosinophil kinetics of $\mathrm{A} / \mathrm{Sn}$ deviating from that of C57 mice, though, in that bone marrow eosinophil levels of A/Sn mice presented a sharp drop soon after infection, which might be due to an early inhibition of eosinopoiesis and a consequent impossibility of replacement of the cells which migrated to the peritoneal space, initial site of infection. Such a slight difference in eosinophil kinetics between $\mathrm{C} 57$ and $\mathrm{A} / \mathrm{Sn}$ mice might contribute but not be responsible for the great variation in susceptibility to $\mathbf{T}$. cruzi infection observed between the two strains. Actually, the difference in eosinophil kinetics observed between the two mice strains, may be a reflection of the difference in the $\mathrm{T}$ cell response to $\mathbf{T}$. cruzi infection, since the control of eosinophilia is mediated by a lymphokine, interchangeably ter med eosinophil differentiation factor (EDF) and interleukin-5 (IL-5) $)^{15}$. 
NAKHLE, M. C.: MENEZES, M. da C. S. de \& IRULEGUI. I. - Eosinophil levels in the acute phase of experimental Chagas' disease. Rev. Inst. Med. trop. S. Paulo, 3161 ) 384 391, 1899

\section{RESUMO}

\section{Níveis de eosinófilos na fase aguda da doença de Chagas experimental.}

A dinâmica de eosinófilos, na medula óssea, sangue e exsudato peritoneal, de uma linhagem de camundongos resistente (C57B1/6) e de uma susceptivel (A/Snell) foi comparativamente es tudada durante a fase aguda da infecção com a cepa $Y$ do Trypanosoma cruzi

Foi observada uma queda nos níveis de eosinófilos da medula óssea nos camundongos $\mathrm{A} / \mathrm{Sn}$, mas nāo nos C57, logo após a infecção, os dos primeiros permanecendo significativamente abaixo dos niveis dos últimos até o 4. dia de infecção. Os níveis de eosinófilos da medula ós sea nos camundongos C57 caíram subseqüente mente a níveis próximos aos dos camundongos A/Sn, o número destas células neste comparti mento permanecendo em torno de $50 \%$ daqueles dos controles não infectados, em ambas as linhagens, até o término do experimento, no 14: dia.

As flutuações nos niveis de eosinófilos no sangue e cavidade peritoneal foram semelhantes nas duas linhagens de camundongos estudadas. Concomitantemente com a depleçāo na medula, ocorreram depleção destas células no sangue e significativo aumento na cavidade peritoneal, foco inicial da infecção, em ambas linhagens de camundongos.

A diferença nos niveis de eosinófilos da me dula ossea entre os camundongos C57 e A/Sn observada nos 4 primeiros dias de infecção, sugere uma maior capacidade de eosinopoiese dos primeiros nesse período, o que poderia contri buir para sua maior resistência à infecção pelo T. cruzi.

\section{ACKNOWLEDGEMENT}

We are indebted to Drs. Junko Takano Osa ka and Lucí Ebisui, of the Central Animal House of Faculdade de Medicina da Universidade de São Paulo, for the animals supplied.

\section{REFERENCES}

1. ALCANTARA, A. \& BRENER, Z. - The "in vitro"interac tion of Trypanosoma cruzi bloodstream forms and mouse peritoneal macrophages. Acta trop. (Basel), 35: 209-219. 1978

2. ANDRADE, S. G. - Caracterizaçāo de cepas do Trypanosoma cruzi isoladas no Reconcavo Baiano (Contribuiça ao estudo da patologia geral da doença de Chagas em nosso meiol Rev. Pat trop., 3: 65-121, 1974

3. ANDRADE, S. G: ANDRADE, V : BRODSKIN, C.: MA GALHAEES, J. B. \& BARRAL-NETTO M - Immunolo. gical response of Swiss mice to infection with three diffe rent strains of Trypanosoma cruzi. Ann. trop. Med. Parasit., 29: 397-407, 1985

4. ANDRADE, V: BARRAL-NETTO $M$ \& ANDRADE $S$ G - Patterns of resistance of inbred mice to Trypanosoma cruzi are determined by parasite strain. Braz. J. med. biol. Res., 18: 499. 506, 1985

5. BERQUO, E. S.; SOUSA, J. M. P. \& GOTLIEB, S. L. D - Bioestatística. Sảo Paulo. Ed. Pedagógica e Univer sitária, 1981.p. 84

6. CONOVER, W. J. - Practical nonparametric statistics. New York, Wiley \& Sons. 1980. p. 216.

7. DISCOMBE, G. - Criteria of eosinophilia. Lancet, $195-196,1946$.

8. GLEICH. G.J.\& ADOLPHSON, C. R. - The eosinophilic leukocyte: structure and function. Adv. Immunol., 39: $177-253,1986$

9. KIERSZENBAUM, F. - Antibody-dependent killing of bloodstream forms of Trypanosoma cruzi by human peripheral blood leukocytes. Amer. J. trop. Med. Hyg., 28: $965-968,1979$

10. KIERSZENBAUM. F.: ACKERMAN, S. J. \& GLEICH. G. J. - Destruction of bloodstream forms of Trypanosoma cruzi by eosinophil granule major basic protein Amer. J. trop. Med. Hyg., 30: 775779,1981

11. KIERSZENBAUM, F.; VILLALTA, F. \& TAI, P.C. - Role of inflammatory cells in Chagas' disease. III. Kinetics of human eosinophil activation upon interaction with para sites (Trypanosoma cruzi). J. Im munol., 136: 662 666. 1986

12. KIPNIS, T. L, JAMES. S. L.; SHER, A. \& DAVID, J. R - Cell-mediated cytotoxicity to Trypanosoma cruzi. II. Antibody-dependent killing of bloodstream forms by mou se eosinophils and neutrophils. Amer. J. trop. med. Hyg. 30: $47-53,1981$

13. MOLINA, H. A.; KIERSZENBAUM, F.: HAMANN, K. J \& GLEICH, G. J. - Toxic effects produced or mediated by human eosinophil granule components on Trypanosoma cruzi. Amer. J. trop. Med. Hyg., 38: 327 334. 1988.

14. ROWLAND, E. C. \& SIBLEY PHILLIPS, S. - Bone mar row eosinophil levels in Trypanosoma cruzi infected mice. J. Parasit., jo: 819-820, 1984 
NAKHLE. M. C.: MENEZES, M. da C. S. de \& IRULEGUI, I. - Eosinophil levels in the acute phase of experimental Chagas' disease. Rev. Inst. Med. trop. S. Paulo, 31(6): 384-391, 1989.

15. SANDERSON, C. J.: CAMPBELL, H. D. \& YOUNG, I. G. - Molecular and cellular biology of eosinophil differen tiation factor (Interleukin .5) and its effects on human and mouse B cells. Immunol. Rev., 102: 29-50, 1988.

16. SANDERSON, C. J. \& DE SOUZA, W. - A morphological study of the interaction between Trypanosoma cruzi and rat eosinophils, neutrophils and macrophages "in vitro". J. Cell Sci., 37: 257-286, 1979

17. TRISCHMANN, T. M. \& BLOOM. B. R. - Genetics of murine resistance to Trypanosoma cruzi. Infect. Immun., 35: 546551,1982
18. TRISCHMANN, T.: TANOWITZ, H.: WITTNER, M. \& BLOOM. B. - Trypanosoma cruzi: role of the immune response in the natural resistance of inbred strains of mice Exp. Parasit., 45: 160-168, 1978

19. VILLALTA, F. \& KIERSZENBAUM, F - Role of inflam matory cells in Chagas'disease. I. Uptake and mechanism of destruction of intracellular r amastigotel forms of Trypanosoma cruzi: by human eosinophils. J. Immunol., 132: 2053-2058. 1984.

Recebido para publicação em 1561989 